\title{
Annual monitoring of DMS-producing bacteria in Tokyo Bay, Japan, in relation to DMSP
}

\author{
Takushi Niki ${ }^{1, *}$, Masayuki Kunugi $^{2}$, Kunio Kohata ${ }^{2}$, Akira Otsuki ${ }^{1}$ \\ 'Department of Marine Science and Technology, Tokyo University of Fisheries, 4-5-7 Kounan, Minato-ku, Tokyo 108, Japan \\ ${ }^{2}$ National Institute for Environmental Studies, 16-2 Onogawa, Tsukuba, Ibaraki 305, Japan
}

\begin{abstract}
The population of dimethylsulfide (DMS)-producing bacteria together with the DMS and dimethylsulfoniopropionate (DMSP) concentrations were monitored from July 1995 to August 1996 in Tokyo Bay, Japan. The concentration of DMS varied widely in the range from 2 to $130 \mathrm{nM}$, and the total, dissolved and particulate DMSP concentrations varied from 5 to $220 \mathrm{nM}$, from below the detection limit to $75 \mathrm{nM}$, and from 5 to $200 \mathrm{nM}$, respectively. The observed particulate DMSP concentration was well explained by the DMSP attributable to Dinophyceae, estimated from the species-specific DMSP per cell contents. The population of DMS-producing bacteria enumerated by the Most Probable Number method was in the range from $1.6 \times 10^{3}$ to $9.2 \times 10^{4}$ cells $\mathrm{ml}^{-1}$ A positive relationship was found between the population of DMS-producing bacteria and the total DMSP concentration in some months, suggesting an important role of bacteria in DMS production. However, some other data points showed the small population of DMS-producing bacteria in spite of the high concentrations of DMS and total DMSP. These data did not agree with the above relationship and suggest a contribution of non-bacterial DMS production under certain circumstances.
\end{abstract}

KEY WORDS: Dimethylsulfoniopropionate - Dimethylsulfide $\cdot$ Bacteria Dinophyceae

\section{INTRODUCTION}

Dimethylsulfide (DMS) constitutes the major proportion of volatile organic sulfur compounds in the marine environment (Andreae 1985), and its flux to the atmosphere is considered to be one of the most important biogenic sources of non-sea-salt-sulfate (nss-sulfate) aerosols. These nss-sulfate aerosols are important as cloud-condensation nuclei (CCN), which affect the earth's albedo and, hence, the global climate. Thus, the biological climate regulation hypothesis proposed by Charlson et al. (1987) is of great interest with respect to the biogeochemical cycling of oceanic DMS

It is known that DMS is derived from biological transformation of $\beta$-dimethylsulfoniopropionate (DMSP). DMSP is produced by certain phytoplankton species, especially members of the Prymnesiophyceae and Dinophyceae (Keller et al. 1989, Belviso et al. 1990, Gibson et al. 1990). However, many previous

·E-mail: nikit@nies.go.jp works have revealed no direct correlation between DMS concentration and phytoplankton biomass in the field (Turner et al. 1989, Belviso et al. 1993, Holligan et al. 1993). Bacterial degradation of dissolved DMSP has been regarded as one of the most important processes in DMS production due to the ubiquity of dissolved DMSP in sea water and the high rate of bacterial consumption of dissolved DMSP (Kiene 1990, 1992, Bates et al. 1994, Kwint \& Kramer 1996).

Release of DMSP from phytoplankton cells to the dissolved pool is necessary for bacterial DMS production. Some processes, such as senescence of phytoplankton (Stefels \& van Boekel 1993, Kwint \& Kramer 1995), zooplankton grazing (Leck et al. 1990, Christaki et al. 1996) and viral infection (Bratbak et al. 1995), have been proposed as mechanisms of DMSP release from phytoplankton cells to sea water. However, information about the relationship between bacterial DMS production activity and DMSP production in natural marine systems is quite scarce.

In the present study, not only the DMSP and DMS concentrations but also the population of DMS-produc- 
ing bacteria were investigated in Tokyo Bay, Japan, during the period from July 1995 to August 1996. The main aim of this study was to investigate the relationship between the DMS-producing bacteria and the DMSP and DMS occurrence in a marine environment, and to evaluate the role of bacteria in DMS production.

\section{MATERIALS AND METHODS}

Sample collection. Surface seawater samples were collected approximately monthly (sampling was not conducted in October and November 1995 and June 1996 due to bad weather) at Stn B (Fig. 1; 35 33' N, $\left.139^{\circ} 54^{\prime} \mathrm{E}\right)$, located at the head of Tokyo Bay, during survey cruises of the vessels 'Kiyosumi' of Chiba Prefecture and 'Hiyodori' of the Tokyo University of Fisheries. Samples for DMS and DMSP analysis and bacterial enumeration were collected in $2 \mathrm{HCl}$-rinsed $1 \mathrm{l}$ polyethylene bottles washed thoroughly with sea water from the sampling site before collection. Pigment samples were collected in 21 polyethylene bottles. No fixation procedure was applied to these sam-

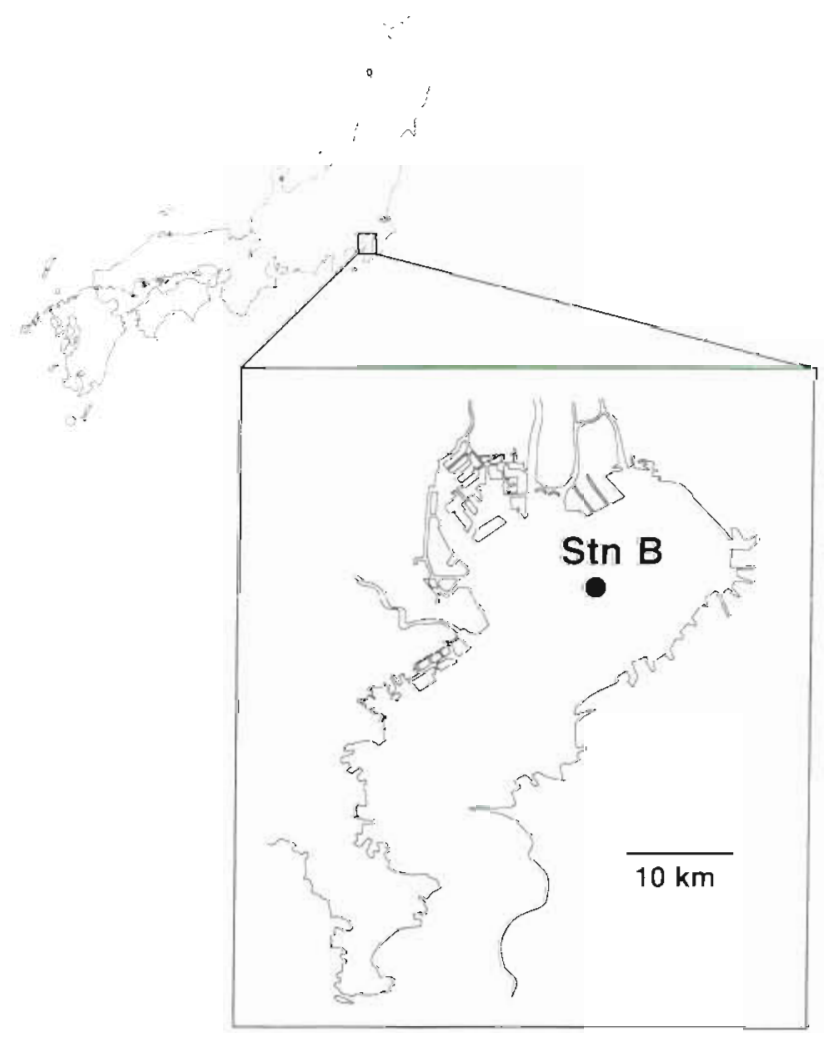

Fig. 1 Tokyo Bay, Japan, sampling site of this study (Stn B) ples. Samples for light microscopic phytoplankton enumeration were taken in 11 and $500 \mathrm{ml}$ polyethylene bottles. Samples taken in the former were fixed with glutaraldehyde (final concentration $1 \%$ ) and those taken in the latter were not fixed. All samples were stored in a cool box and prepared for analysis in the laboratory within $8 \mathrm{~h}$ of collection.

Analysis. A purge and trap/gas chromatography method was employed for DMS analysis. Between 1 and $10 \mathrm{ml}$ of sample was carefully transferred to the sparging device. The sparging duration was $10 \mathrm{~min}$ at $100 \mathrm{ml} \mathrm{min}{ }^{-1}$ nitrogen flow. Stripped DMS was adsorbed to porous polymer (Tenax TA; GL Science Inc, Tokyo) in a straight glass tube at $-20^{\circ} \mathrm{C}$ through a gas-drying condenser (U-shaped empty glass tube chilled at $-20^{\circ} \mathrm{C}$ ). No obvious loss of DMS in the condenser was observed. DMS retained in the Tenax tube was injected to the gas chromatograph (GC) system with a TCT (Thermal-desorption Cold Trap injector; CHROMPACK) attached to a Hewlett-Packard 5890A series II GC equipped with a flame photometric detector (FPD). A PoraPLOT Q $(0.32 \mathrm{~mm} \times 25 \mathrm{~m}$ i CHROMPACK) column was used and the carrier gas was helium at $2 \mathrm{ml} \mathrm{min}{ }^{-1}$. The column temperature was linearly programmed to increase from 100 to $200^{\circ} \mathrm{C}$ at $15^{\circ} \mathrm{C} \mathrm{min}-1$ and then held at $200^{\circ} \mathrm{C}$ for $5 \mathrm{~min}$. The detection limit of the whole system was about $0.06 \mathrm{nM}$ DMS when a $10 \mathrm{ml}$ sample was analyzed.

In the present study, 3 DMSP concentrations, total, dissolved and particulate, were determined. Dissolved. DMSP (DMSP $P_{d}$ ) was defined as that in the filtrate after gravity filtration through a Whatman GF/F filter (Keller et al. 1989). Particulate DMSP (DMSP $)$ was calculated by subtracting DMSP from total DMSP $\left(\mathrm{DMSP}_{\mathrm{t}}\right)$. Filtrations were performed in the laboratory and did not take longer than $10 \mathrm{~min}$. Between 1 and $10 \mathrm{ml}$ of total water sample (for DMSP ) or GF/F filtrate (for DMSP $\mathrm{d}_{\mathrm{d}}$ ) was sparged for $10 \mathrm{~min}$ to remove DMS, then 1 to $2 \mathrm{ml}$ of $5 \mathrm{~N} \mathrm{NaOH}$ was added to convert DMSP to DMS (Dacey \& Blough 1987), which was determined by the GC system described above. After the DMSP analysis, further DMS yield in the samples was not detected.

Photosynthetic pigments were analyzed by an HPLC. system (Kohata et al. 1991). Sample aliquots of 200 to $500 \mathrm{ml}$ were filtered through $\mathrm{GF} / \mathrm{F}$ filters. These filters were stored at $-20^{\circ} \mathrm{C}$ until the analysis, which was carried out within 2 mo. Pigments on the filters were extracted in $10 \mathrm{ml}$ of $90 \%$ acetone by filter homogenization. The pigment extracts $(100$ to $400 \mu l)$ were injected directly into the HPLC system.

Bacterial enumeration. Two bacterial populations, 'DMS-producing bacteria' and 'DOC utilizers', were enumerated by the Most Probable Number (MPN) method (de Man 1975, Visscher et al. 1992). In the present study, 'DMS-producing bacteria' were defined as 
Table 1. Organic substrates in MPN media for each population $\left(\mathrm{mg} \mathrm{l}^{-1}\right)$

\begin{tabular}{|lcc|}
\hline Organic substrates & DOC utilizers & $\begin{array}{c}\text { DMS-producing } \\
\text { bacteria }\end{array}$ \\
\hline DMSP (as chloride) & 170 & 170 \\
Sodium glutamate & 500 & \\
Glycine & 100 & \\
D.L-Alanine & 100 & \\
Trypticase & 200 & \\
Glucose & 200 & \\
Sucrose & 1000 \\
\hline
\end{tabular}

bacteria which produced DMS from DMSP, and 'DOC utilizers' were defined as bacteria which grew in a mixture of some dissolved organic substrates. The MPN media were based on STP media, which was used for bacteria-free check of algal strains (Watanabe \& Satake 1991), but the organic composition was modified for each population as noted in Table 1 . The soil extract was replaced by a trace element solution $(1 \mathrm{ml}$ $\mathrm{l}^{-1}$; Widdel \& Pfennig 1981) to remove uncertainty about the medium's chemical composition.

Each duplicated sample was diluted from $10^{-1}$ to $10^{-6}$ with GF/F-filtered, autoclaved, aged sea water. Aliquots ( $1 \mathrm{ml}$ ) of diluted subsamples were injected into $10 \mathrm{ml}$ media in $25 \mathrm{ml}$ glass test tubes, and capped with polypropylene screw caps. Controls consisted of each substrate without inoculum. All incubations were carried out at $25^{\circ} \mathrm{C}$ in the dark. Each tube was vortexed daily to mix media with oxygen.

Growth of DOC utilizers on the mixture of organic substrates was checked by observing the turbidity of the media. Growth of DOC utilizers was terminated within 4 to $6 \mathrm{~d}$. Growth of DMS-producing bacteria on DMSP was checked by observing the DMS production in each tube. DMS production was checked by analyzing for DMS in the headspace gas. Headspace analyses were carried out $7 \mathrm{~d}$ after inoculation. Headspace gas (5 ml) was sampled from each tube, and directly injected to TCT to analyze DMS by the GC/FPD system described above. The final size of each bacterial population was determined according to de Man (1975).

\section{RESULTS}

\section{DMSP and DMS}

The DMSP $_{1}$ concentration showed large variation during the study period (Fig. 2a). The highest concentration was $220 \mathrm{nM}$ in July and August 1995, and the lowest concentration was $5 \mathrm{nM}$ in January 1996. The DMSP, concentration increased in February 1996, and ranged from 50 to $160 \mathrm{nM}$ during February to August
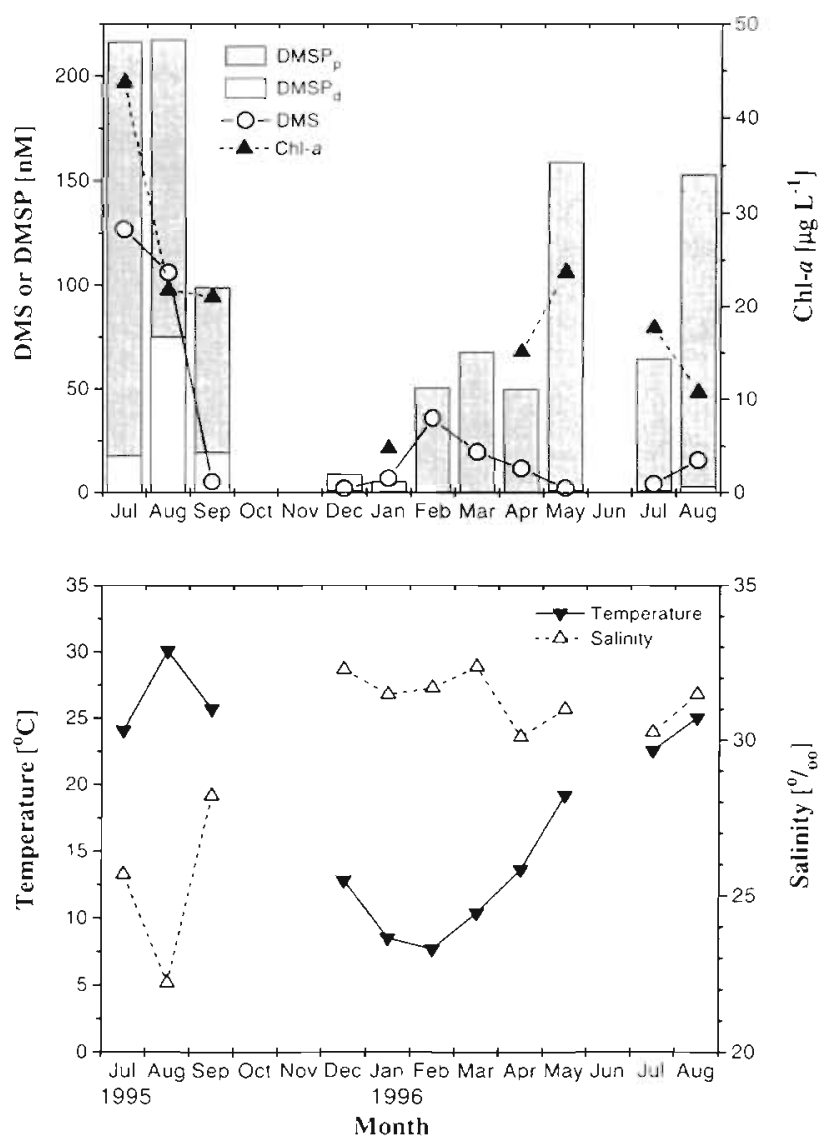

Fig. 2. (a) DMS, DMSP and chlorophyll a concentrations in Tokyo Bay (Japan) from July 1995 to August 1996. The height of each bar indicates DMSP. (b) Temperature and salinity variations

1996. In contrast, the $\mathrm{DMSP}_{\mathrm{d}}$ concentrations did not exceed $20 \mathrm{nM}$ throughout the study period, except for a very high concentration of $73 \mathrm{nM}$ observed in August 1995 (Fig. 2a). From December 1995 onward, the DMSP $_{d}$ concentrations were always lower than $3 \mathrm{nM}$ and even fell below the detection limit in February and

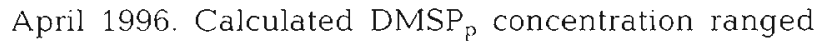
from $5 \mathrm{nM}$ in January 1996 to $200 \mathrm{nM}$ in July 1995. The relative proportion of $D M S P_{d}$ in $D M S P_{t}$ ranged from 0 to $35 \%$.

The DMS concentration also varied very widely (Fig. 2a). The highest DMS concentration was $130 \mathrm{nM}$ in July 1995, and a concentration of more than $100 \mathrm{nM}$ was also observed in the next month. August 1995 (110 nM). The lowest concentration was $2 \mathrm{nM}$ in December 1995 and May 1996. In February 1996, the DMS concentration increased to $36 \mathrm{nM}$ and showed a small peak of concentration. However, in spite of the increase in DMSP, concentration, the DMS concentration did not show further increases in spring and summer of 1996 (from March to August), having lower concentrations than that observed in February 1996. 


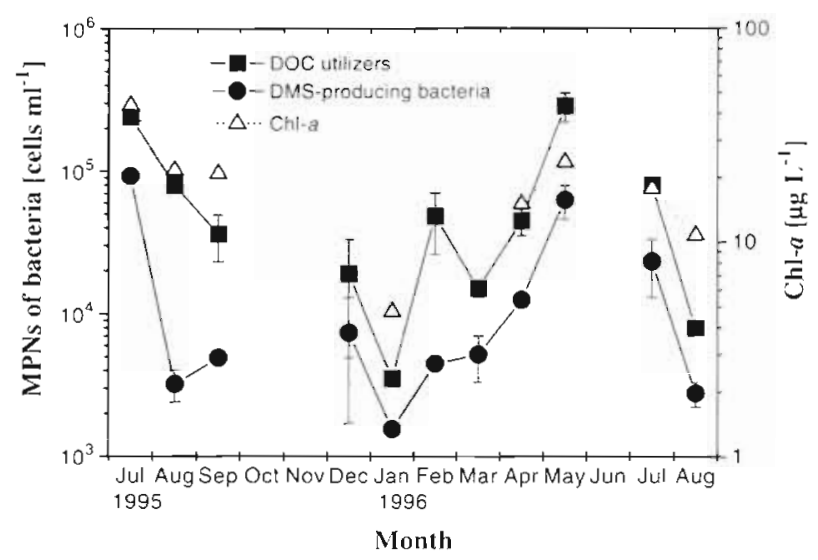

Fig. 3. Populations (MPN: Most Probable Number) of DOC utilizers and DMS-producing bacteria, and chlorophyll a concentration. Each point indicates the average value of the 2 MPNs obtained from each enumeration of duplicated samples and the range is shown by the error bar

Changes in DMS concentration did not correspond to DMSP $_{t}$ DMSP $_{p}$ or DMSP ${ }_{d}$ concentrations (Fig. 2a).

The water temperature ranged from 7.7 to $30.1^{\circ} \mathrm{C}$ during the study period, and the salinity ranged from 22.2 to $32.4 \%$ (Fig. 2b). The low salinity (below $30 \%$ ) was observed from July 1995 to September 1995, when the high concentrations of $\mathrm{DMSP}_{\mathrm{d}}$ were observed (18 to $75 \mathrm{nM}_{\mathrm{i}}$ Fig. 2a).

\section{MPN enumeration of bacteria}

The population of DOC utilizers ranged from $3.5 \times$ $10^{3}$ cells ml $\mathrm{ml}^{-1}$ in January 1996 to $2.9 \times 10^{5}$ cells $\mathrm{ml}^{-1}$ in May 1996 (Fig. 3). The population of DOC utilizers showed a small peak in February 1996. The maximum population of DMS-producing bacteria was $9.2 \times 10^{4}$ cells $\mathrm{ml}^{-1}$ in July 1995. However, in the next month, August 1995, the population of DMS-producing bacteria decreased drastically to $3.2 \times 10^{3}$ cells $\mathrm{ml}^{-1}$, the third lowest value observed. The minimum population was $1.6 \times 10^{3}$ cells $\mathrm{ml}^{-1}$ in January 1996 (Fig. 3). Although changes in population of DMS-producing bacteria generally appeared to reflect those in DOC utilizers, the relative proportion of DMS-producing bacteria to DOC utilizers was not constant, varying from 4 to $44 \%$ (Fig. 4). The smallest proportions of DMS-producing bacteria were found in August 1995 and February 1996 ( 4 and $9 \%$, respectively).

\section{Phytoplankton species}

Bacillariophyceae and Dinophyceae were observed throughout the study period (Fig. 5). Since species

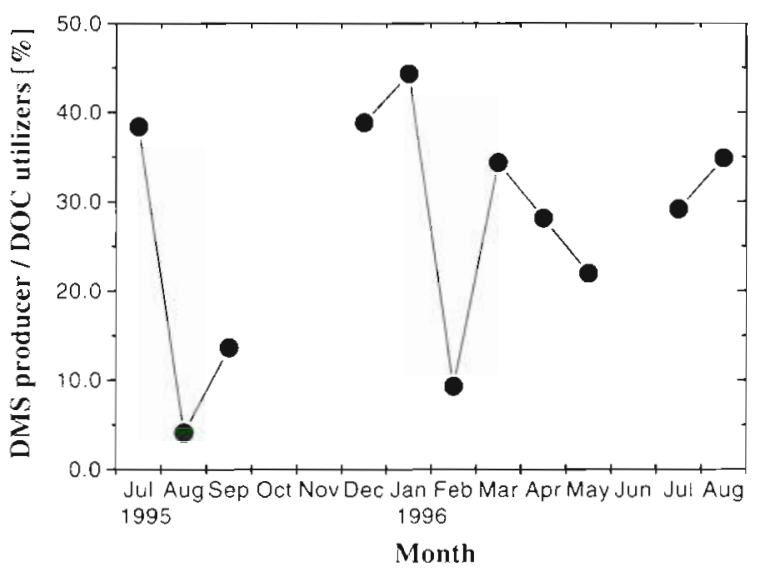

Fig. 4. Relative proportion of DMS-producing bacteria to total DOC utilizers $(\%)$

identification was done with a light microscope, picoand small nanophytoplankton could not be precisely identified and were enumerated collectively as 'microflagellates' (Fig. 5). In July 1995, this fraction constituted $93 \%$ of the total algal cell number. Other identified phytoplankton classes were enumerated collectively as 'others'. Although this fraction constituted more than one-third of total algal cell number in May 1996, the largest fraction in this month was that of Heterosigma akashiwo (Raphidophyceae), which does not produce DMSP (S. Takizawa, M. Kunugi, M. Watanabe \& T. Higashi pers. comm.). In the other months, the 'others' fraction constituted less than $18 \%$, and was mainly comprised of Euglenophyceae and Cryptophyceae.

Although pigment analyses were not conducted in all months, chlorophyll a (chl a) concentrations ranged from $4.8 \mathrm{ug} \mathrm{l}^{-1}$ in January 1996 to $43.7 \mu \mathrm{g} \mathrm{l}^{-1}$ in July 1995. Changes in chl a concentration were dissimilar to

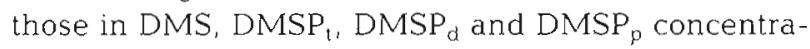
tions (Fig. 2a)

\section{DISCUSSION}

\section{Origin of DMSP production}

The DMSP concentration depends largely on phytoplankton species composition rather than total phytoplankton biomass (Turner et al. 1989, Belviso et al. 1990, Malin et al. 1993). Also, in this study, changes in DMSP concentration were not coupled with those in chl a (Fig. 2a). The results of phytoplankton enumeration showed that the changes in $\mathrm{DMSP}_{\mathrm{p}}$ concentration were more similar to those in Dinophyceae abundance than those in the other categories or total algal cells (Fig. 5). When the July 1995 data were excluded, due to the ex- 
traordinary abundance of microflagellates at that time, a significant correlation was found between Dinophyceae abundance and observed $\mathrm{DMSP}_{\mathrm{p}}$ concentration $(r=0.75, n=9)$. These results suggested a significant contribution of Dinophyceae to the DMSP pool. However, Dinophyceae constituted only small fraction of total algal cells (see $y$-axes of Fig. 5). Therefore, the $\operatorname{DMSP}_{\mathrm{p}}$ concentration attributable to the dominant Dinophyceae species $\left(\right.$ DMSP $\left._{\text {Dino }}\right)$ was estimated. The dominant Dinophyceae species in this study were as follows, where the used DMSP per cell content, which were taken from Keller et al. (1989), are shown in parentheses: Gymnodiniales $(0.69 \mathrm{pmol}$ cell $^{-1}$ ), Prorocentrum spp. (represented by $P$. minimum, 0.16 pmol cell ${ }^{-1}$ ), Protoperidinium spp. (represented by the average value of reported Peridiniales, $\left.0.96 \mathrm{pmol}^{\mathrm{c}} \mathrm{cll}^{-1}\right)$, Ceratium spp. $\left(0.01 \mathrm{pmol}^{\mathrm{cell}}{ }^{-1}\right)$, Heterocapsa spp. (0.37 pmol cell $\left.{ }^{-1}\right)$ and Scrippsiella spp. $\left(2.84 \mathrm{pmol}^{\mathrm{c}} \mathrm{cel}^{-1}\right)$. Throughout the study period, these dominant species constituted more than $80 \%$ of the total Dinophyceae cells observed at our study site.

The observed $\mathrm{DMSP}_{\mathrm{p}}$ concentration was well explained by the calculated $\mathrm{DMSP}_{\text {Dino }}$ (Fig. 6). A higher correlation coefficient was obtained $(\mathrm{r}=0.85)$ when the data for July 1995 were excluded for the reason stated above. These results indicate that most of the DMSP $_{p}$ pool in the months other than July 1995 was contributed by Dinophyceae. Although DMSP per cell contents of Dinophyceae have been reported to vary over the growth cycle (Matrai \& Keller 1994), such differences in DMSP content may be averaged in complex natural phytoplankton communities. The good correlation found in this study suggests the possibility that DMSP content data obtained from culture experiments is applicable to natural environments to estimate the size of DMSP $_{p}$ pool from available phytoplankton data.

In July 1995, the DMSP Dino was calculated to be $28.8 \mathrm{nM}$, accounting for only $15 \%$ of actual DMSP $_{p}$ $(200 \mathrm{nM})$. The $\mathrm{DMSP}_{\mathrm{p}}$ attributable to Bacillariophyceae was also calculated (only $3.0 \mathrm{nM}$ ), but did not account for the discrepancy between the DMSP $_{\text {Dino }}$ and the observed $\operatorname{DMSP}_{\mathrm{p}}$. Carotenoid analysis of samples taken at that time revealed a high concentration

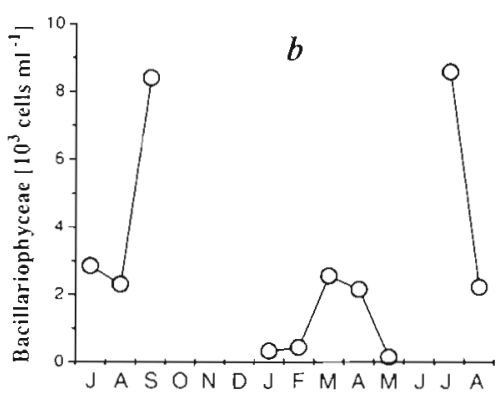

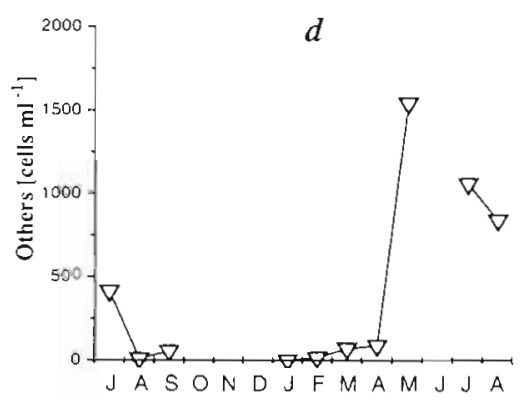
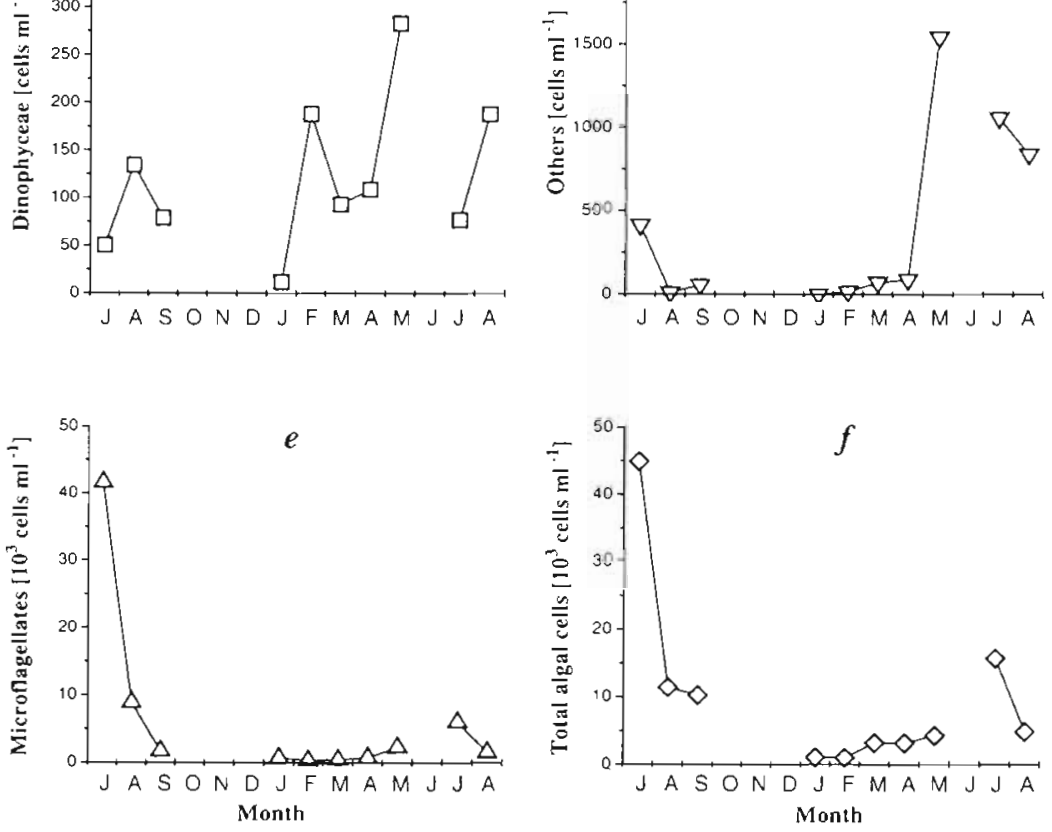

Fig. 5. (a) DMSP $\mathrm{p}_{\mathrm{p}}$ concentration and (b-f) phytoplankton abundance in Tokyo Bay. (b) Bacillariophyceae, (c) Dinophyceae, (d) others, (e) microflagellates, and (f) total algal cells

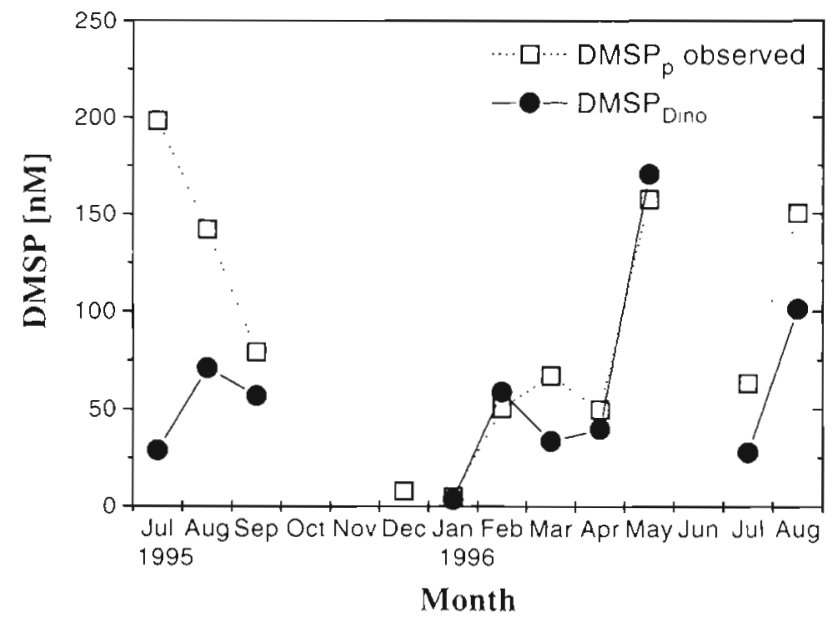

Fig. 6. Observed DMSP concentration and estimates of contribution by Dinophyceae, DMSP Dino $_{\text {. }}$ 
$\left(1.6 \mu \mathrm{gl}^{-1}\right)$ of $19^{\prime}$-hexanoyloxyfucoxanthin, a characteristic carotenoid of Prymnesiophyceae. Therefore, a significant part of the DMSP in that month can be attributed to Prymnesiophyceae which were probably included in the 'microflagellates' in this study.

\section{Importance of DMS-producing bacteria}

Released DMSP from phytoplankton cells is consumed rapidly by bacteria (Kiene 1992). The rates or kinetics parameters of DMSP $_{d}$ consumption and DMS production in sea water have been reported in some studies (Kiene \& Service 1991, Ledyard \& Dacey 1996). DMS-producing bacteria have also been isolated (Ledyard \& Dacey 1994, de Souza \& Yoch 1995) and enumerated (Visscher et al. 1992). However, information about the seasonal changes in both bacterial activity and population has been quite scarce. In the present study, an annual data set of the population of DMSproducing bacteria was obtained by the MPN method. Due to the selectivity of the media, the MPN method may underestimate the true bacterial population. However, due to its selectivity, this method was considered to be useful for the purpose of observing the seasonal changes in DMS-producing bacteria in this study.

Changes in DMS concentration were not similar to those in the population of DMS-producing bacteria, and no obvious relationship was found between them (Fig. 7b). In the spring of 1996, despite the increase in both the DMSP, concentration and the population of DMS-producing bacteria, the DMS concentration started to decrease from its peak in February, and fell to $2 \mathrm{nM}$ in May (Figs. 2a \& 3). Produced DMS is removed by various processes such as bacterial consumption (Kiene \& Bates 1990, Wolfe \& Kiene 1993, Kwint \& Kramer 1996), photochemical oxidation (Brimblecombe \& Shooter 1986) and escape to the atmosphere. The observed concentration of DMS is the net result of production and removal. The discrepancy between the DMS concentration and the DMSP, concentration and DNIS-producing bacterid population found in this study may be explained by DMS removal.

The seasonal changes in the population of DMS-producing bacteria appeared not to be directly related to those in DMSP concentrations (see Figs. 2a \& 3). However, an interesting relationship appeared in the plots of the population of DMS-producing bacteria versus DMSP: concentration (Fig. 7a). A coupled increase of both the DMSP, concentration and the population of DMS-producing bacteria was shown by some data points (July 1995, May 1996, etc.). An increase in the population of DMS-producing bacteria should be coupled with an increase in the input (production) of

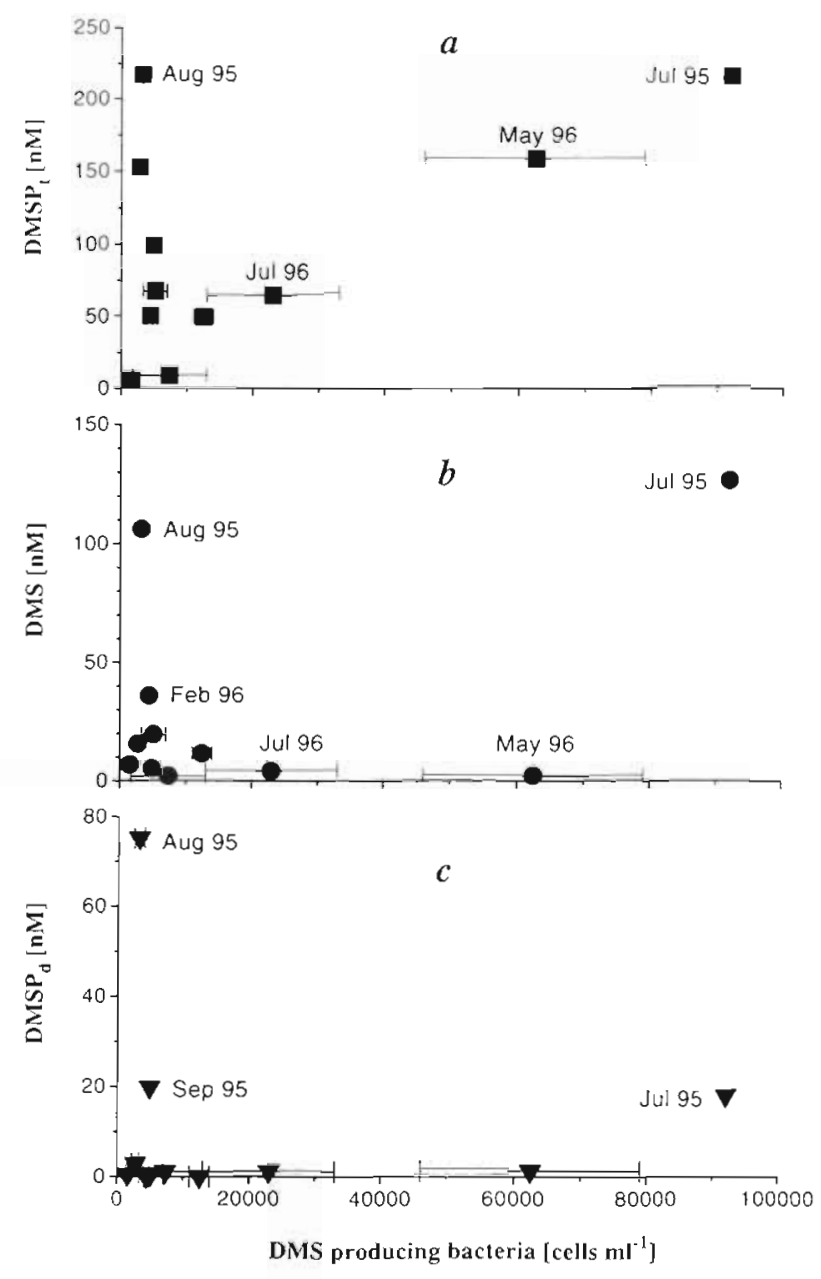

Fig. 7 Relationship between DMS-producing bacteria and

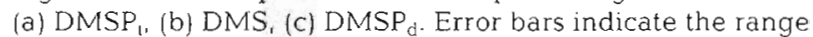
of 2 MPNs obtained from each enumeration of duplicated samples

DMSP $_{d}$. However, the concentrations of DMSP for $_{d}$ these data points were low (Figs. $2 \& 7 \mathrm{c}$ ), possibly due to a rapid turnover of the DMSP by bacteria. Therefore, the above relationship between the DMS-producing bacteria and the DMSP, concentration may suggest that a significant part of produced DMSP could become available for bacteria. These interpretations indicate an important role of bacterial consumption as a sink for DMSP in the environment, and suggest that the bacterial transformation was the most important DMS production process.

However, some other data points, such as August 1995, showed the small population of DMS-producing bacteria in spite of the high DMSP, concentration (Fig. 7a). These points appear to be independent of the positive relationship discussed above. The non-DMSproducing population (demethylator) is also included in the total DMSP-consuming population (Visscher et 
al. 1992), but was not determined in this study since the DMS analysis was used for checking the bacterial growth on DMSP. The relative proportion of the DMSproducing bacteria to the total DMSP-consuming population might have decreased in these months. The data for August 1995 and February 1996 showed a high DMS concentration but a small population of DMS-producing bacteria (Fig. 7b). In these 2 months, the proportions of DMS-producing bacteria to DOC utilizers were also small ( 4 and $9 \%$, respectively; Fig. 4). These data appear to disagree with the hypothesis that bacteria are important in DMS production. Some previous studies have reported non-bacterial DMSP-lyase activity (Kadota \& Ishida 1968, Stefels \& van Boekel 1993). Stefels et al. (1995) showed that DMSP-lyase activity in the early stage of a Phaeocystis sp. bloom was mostly attributable to Phaeocystis itself. There are also some reports that microzooplankton and detritus are important in DMS production (Belviso et al. 1993, Christaki et al. 1996). In this study, large tintinnids were extraordinary abundant $(>100 \mu \mathrm{m}$ in length, not precisely enumerated but probably more than 10 ind. $\mathrm{ml}^{-1}$ ) in the February 1996 sample. The discrepancy between the DMS concentration and population of DMS-producing bacteria may suggest a contribution of non-bacterial DMS production in these months.

These results stress the need for further research on DMSP $_{d}$ generation and non-bacterial DMS production process(es), such as larger particle-associated DMSPlyase activity, in natural marine environments.

Acknowledgements. We thank the captains and crews of the ships 'Kiyosumi' and 'Hiyodori' for making our sampling possible, Dr Y Nakamura for help in sampling and valuable suggestions, S. Shibuya for technical assistance in pigment analysis, and $M$. Gonda for phytoplankton identification.

\section{LITERATURE CITED}

Andreae MO (1985) The emission of sulfur to the remote atmosphere: background paper In: Galloway JN, Charlson RJ, Andreae MO, Rodhe $\mathrm{H}$ (eds) The biogeochemical cycling of sulfur and nitrogen in the remote atmosphere. D Reidel Pub Co, Dordrecht, p 5-25

Bates TS, Kiene RP, Wolfe GV, Matrai PA, Chavez FP, Buck KR, Blomquist BW, Cuhel RL (1994) The cycling of sulfur in surface seawater of the northern Pacific. J Geophys Res $99(\mathrm{C} 4): 7835-7843$

Belviso S, Baut-Ménard P, Putaud JP, Nguyen BC, Claustre H, Neveux J (1993) Size distribution of dimethylsulfoniopropionate (DMSP) in areas of the tropical northeastern Atlantic Ocean and the Mediterranean Sea. Mar Chem 44: $55-71$

Belviso S, Kim SK, Rassoulzadegan F, Krajka B, Nguyen BC, Milhalopouls N, Baut-Ménard P (1990) Production of dimethylsulfonium propionate (DMSP) and dimethylsulfide (DMS) by a microbial food web. Limnol Oceanogr 35: $1810-1821$
Bratbak G, Lavesseur M, Michaud S, Cantin G, Fernández E, Heimdal BR, Heldal M (1995) Viral actuvity in relation to Emiliania huxleyi blooms: a mechanism of DMSP release? Mar Ecol Prog Ser 128:133-142

Brimblecombe P. Shooter D (1986) Photo-oxidation of dimethylsulfide in aqueous solution. Mar Chem 19:343-353

Charlson RJ, Lovelock JE, Andreae MO, Warren SG (1987) Oceanic phytoplankton, atmospheric sulfur, cloud albedo and climate. Nature 326:655-661

Christaki U, Belviso S, Dolan JR, Corn M (1996) Assessment of the role of copepods and cilıates in the release to solution of particulate DMSP. Mar Ecol Prog Ser 141 $119-127$

Dacey JWH, Blough NV (1987) Hydroxide decomposition of dimethylsulfoniopropionate to form dimethylsulfide. Geophys Res Lett 14(12):1246-1249

de Man JC (1975) The probability of Most Probable: Numbers. Eur J Appl Microbiol 1:67-78

de Souza MP, Yoch DC (1995) Comparative physiology of dimethyl sulfide production by dimethylsulfoniopropionate lyase in Pseudomonas doudoroffil and Alcaligenes sp. strain M3A Appl Environ Microbiol 61:3986-3991

Gibson JAE, Garnck RC, Burton HR, McTaggart AR (1990) Dimethylsulfide and the alga Phaeocystis poucheti in Antarctic coastal waters. Mar Biol 104:339-346

Holligan PM, Fernandez E, Aiken J, Balch WM, Boyd P, Burkill PH, Finch M, Groom SB, Malin G, Muller K, Purdie DA, Robinson C, Trees CC, Turner SM, van del Wal P (1993) A biogeochemical study of the coccolithophore, Enuliania huxleyi, in the North Atlantic. Global 13iogeochem Cycles 7:879-900

Kadota $H_{4}$ lshida $Y$ (1968) Effect of salts on enzymatical production of dimethyl sulfide: from Gyrodinium cohnii. Bull Jpn Soc Sci Fish 34(6):512- 18

Keller MD, Bellows WK, Guillard RRL (1989) Dimethylsulfide production in marine phytoplankton. In: Saltsman ES, Cooper WJ (eds) Biogenic sulfur in the environment. Am Chem Soc Pub, Washington, DC, p 167-182

Kiene RP (1990) Dimethyl sulfide production from dimethylsulfoniopropionate in coastal seawater samples and bacterial cultures. Appl Environ Microbiol 56:3292-3297

Kiene RP (1992) Dynamics of dimethylsulfide and dimethylsulfoniopropionate in oceanic water samples. Mar Chem 37:29-52

Kiene RP, Bates TS (1990) Biological removal of dimethyl sulphide from sea water. Nature 345:702-705

Kiene RP, Service SK (1991) Decomposition of dissolved DMSP and DMS in estuarine water: dependence on temperature and substrate concentration. Mar Ecol Prog Ser $76: 111$

Kohata K. Watanabe M, Yamanaka K (1991) Highly sensitive determination of photosynthetic pigments in marine in situ samples by high-performance liquid chromatography. J Chromatogr 294:131-140

Kwint RLJ, Kramer KJM (1995) Dimethylsulphide production by plankton communities. Mar Ecol Prog Ser 121:227-237

Kwint RLJ, Kramer KJM (1996) Annual cycles of the production and fate of DMS and DMSP in a marine coastal system. Mar Ecol Prog Ser 134:217-224

Leck C, Larsson U, Bågander LE, Johansson S, Hajdu S (1990) Dimethylsulfide in the Baltic Sea: annual variabılity in relation to biological activity. J Geophys Res 93(C3): $3353-3363$

Ledyard KM, Dacey JWH (1994) Dimethylsulfide production from dimethlylsulfoniopropionate by a marine bacterium. Mar Ecol Prog Ser 110:95-103

Ledyard KM, Dacey JWH (1996) Microbial cycling of DMSP 
and DMS in coastal and oligotrophic seawater. Limnol Oceanogr 41(1):33-40

Malin G, Turner S, Liss P, Holligan P, Harbour D (1993) Dimethylsulphide and dimethylsulphoniopropionate in the Northeast Atlantic during the summer coccolithophore bloom. Deep Sea Res 40(7):1487-1508

Matrai PA, Keller MD (1994) Total organic sulfur and dimethylsulfoniopropionate in marine phytoplankton: intracellular variations. Mar Biol 119:61-68

Stefels J, Dijkhuizen L, Gieskes WWC (1995) DMSP-lyase activity in a spring phytoplankton bloom off the Dutch coast, related to Phaeocystis sp. abundance. Mar Ecol Prog Ser 123:235-243

Stefels J, van Boekel WHM (1993) Production of DMS from dis solved DMSP in axenic cultures of the marine phytoplankton species Phaeocystis sp. Mar Ecol Prog Ser 97:11-18

Turner SM, Malin G, Liss PS (1989) Dimethyl sulfide and (dimethylsulfonio)propionate in European coastal and

This article was submitted to the editor shelf waters. In: Saltzman ES, Cooper WJ (eds) Biogenic sulfur in the environment. Am Chem Soc Pub, Washington, DC. p 183-200

Visscher PT, Diaz MR, Taylor BF (1992) Enumeration of bacteria which cleave or demethylate dimethylsulfoniopropionate in the Caribbean Sea. Mar Ecol Prog Ser 89:293-296

Watanabe MM, Satake KN (1991) List of strains, 3rd edn, Microalgae and Protozoa. National Institute for Environmental Studies, Ibaraki, Japan

Widdel F, Pfennig N (1981) Studies on dissimilatory sulfatereducing bacteria that decompose fatty acids: I. Isolation of new sulfate-reducing bacteria enriched with acetate from saline environments. Description of Desulfobacter postgatei gen. nov., sp. nov. Arch Microbiol 129:395-400

Wolfe GV, Kiene RP (1993) Radioisotope and chemical inhibitor measurements of dimethylsulfide consumption rates and kinetics in estuarine waters. Mar Ecol Prog Ser 99:261-269

Manuscript received: January 6, 1997

Revised version accepted: July 10,1997 